\title{
Implementasi Keselamatan Berkendara Pada Anak (Safety Riding For Kids) Terhadap Pengetahuan Keselamatan Berlalu Lintas Pada Siswa TK di Kabupaten Indramayu
}

\author{
The Implementation of Safety Riding for Kids to knowledge of safety ride on Kindergarten students \\ in Indramayu
}

\section{Eko Maulana Syaputra ${ }^{1}$, Tayong Siti Nurbaeti ${ }^{2}$}

Program Studi Kesehatan Masyarakat Universitas Wiralodra ${ }^{1,2}$ email :ekomaulanasyaputra@unwir.ac.id ${ }^{1}$ t.siti.nurbaeti@gmail.com²

\begin{abstract}
Abstrak
Menurut data Polres Indramayu pada tahun 2018 terdapat 107.968 kasus kecelakaan lalu lintas, dimana terdapat 29.083 korban meninggal dunia. Serta terdapat 2.546 korban kecelakaan lalu lintas usia 0-4 tahun. Tingginya kecelakaan lalu lintas terjadi karena masih rendahnya tingkat pengetahuan, orang tua dalam aspek keselamatan berkendara. Ketika mengantar atau menjemput anaknya ke sekolah sebagian besar orang tua tidak memakaikan helm ke anaknya. Padahal anak sangat rentan untuk terjadinya cedera apabila terjadi kecelakaan lalu lintas.

Penelitian ini bertujuan untuk mengetahui pengaruh implementasi safety riding for kids terhadap pengetahuan berlalu lintas pada siswa TK

Sampel terdiri dari 36 siswa kelompok perlakuan dan 47 siswa kelompok kontrol. Jenis penelitian ini adalah penelitian eksperimen semu (quasi experiment) dengan pendekatan non randomized control group pre test post test design.

Hasil penelitian ini menunjukkan pada kelompok perlakuan terdapat perbedaan pengetahuan tentang safety riding sebelum dan sesudah implementasi dengan $p$ value 0,000 . Pada kelompok kontrol tidak terdapat perbedaan pengetahuan safety riding sebelum dan sesudah implementasi dengan $p$ value 0,704 terdapat pengaruh implementasi safety riding for kids terhadap pengetahuan tentang safety riding dengan $p$ value 0,001 .

Diperlukan adanya kesadaran dari orang tua siswa serta perlu adanya kebijakan dan pengawasan dari pihak sekolah tentang pentingnya safety riding untuk anak, khususnya kewajiban pemakaian helm.
\end{abstract}

Kata kunci: safety riding for Kids, Pengetahuan

\section{Abstract}

According to Indramayu police data in 2018, there were 107,968 traffic accidents, where 29,083 traffic accidents victims dead. And there are 2,546 victims of traffic accidents 0-4 years old. High traffic accidents occur because of lack of parental knowledge in terms of riding safety. When they take their children to school, most of parents do not helmet their children. While a child is highly susceptible to injuries in the event of traffic accidents
It aims to know the effects of implementation of safety riding for kids on kindergarten students.

The participants consist of 36 students' treatment group and 47 students control group. This kind of research is the quasiexperimental research with non-randomized control group pre test post test design.

The study shows in treatment groups' differences in the knowledge of safety riding before and after implementation by the $p$ value 0,000 . On the control group there is no differences in safety riding knowledge before and after implementation with the $p$ value 0.704 there is the effect of implementation safety riding for kids against the knowledge of safety riding with the $p$ value 0.001 .

There is need for the awareness of the parents of the students and the need for school policy and the importance of safety riding for the children especially the obligation to use a helmet.

Keyword: safety riding for Kids, knowledge

\section{Pendahuluan}

Menurut data Global Status Report on Road Safety yang dikeluarkan oleh WHO, Indonesia berada di urutan pertama dalam peningkatan kecelakaan. Data dari Satlantas pada tahun 2015, kejadian kecelakaan lalu lintas yang melibatkan anak kecil berjumlah 290 kasus naik 14 persen. Korban meninggal 12 orang (turun 15 persen), luka berat 96 orang (naik 71 persen), dan luka ringan 107 orang (naik 49 persen). Artinya hampir setiap hari terjadi kasus kecelakaan yang melibatkan anak kecil. ${ }^{1}$

Data dari Badan Pusat Statistik (BPS) Provinsi Jawa Barat tahun 2016 menunjukkan bahwa data kecelakaan lalu lintas sebesar 6861 kasus. $^{2}$ Sedangkan, Menurut data Polres Indramayu pada tahun 2018 terdapat 107.968 kasus kecelakaan lalu lintas, dimana terdapat 29.083 korban meninggal dunia. Serta terdapat 
2.546 korban kecelakaan lalu lintas usia 0-4 tahun. Sebagian besar kecelakaan lalu lintas berasal dari sepeda motor. Sehingga, menjadikan Kabupaten Indramayu sebagai penyumbang terbesar kejadian kecelakaan lalu lintas di Provinsi Jawa Barat. ${ }^{3}$

Tingginya kecelakaan lalu lintas terjadi karena masih rendahnya tingkat pengetahuan, orang tua dalam aspek keselamatan berkendara. Ketika mengantar atau menjemput anaknya ke sekolah sebagian besar orang tua tidak memakaikan helm ke anaknya. Padahal anak sangat rentan untuk terjadinya cedera apabila terjadi kecelakaan lalu lintas. Hal ini sejalan dengan penelitian Goniewicz et al, yang menyatakan tingginya kecelakaan lalu lintas pada anak usia dibawah 7 tahun, salah satu penyebabnya karena kurangnya pengawasan dari orang tua. ${ }^{4,5}$

Berdasarkan hasil observasi oleh peneliti mengenai faktor potensial yang dapat mengakibatkan insiden di jalan raya pada siswa sekolah TK tersebut diantaranya adalah: (1) sebagian besar anak sekolah TK ketika diantar dan dijemput orang tuanya ke sekolah tidak menggunakan helm dan perlengkapan keselamatan lainnya (2) sebagian besar orang tua menganggap tidak ada peraturan yang mewajibkan penggunaan helm dan perlengkapan keselamatan berkendara untuk anak-anak (3) berdasarkan wawancara yang telah dilakukan pada beberapa guru sekolah TK diketahui bahwa belum adanya materi atau metode pembelajaran yang mendukung tentang pentingnya penanaman keselamatan berkendara untuk anak (safety riding for kids) di sekolah. Dari permasalahan diatas, peneliti merasa tertarik untuk melakukan penelitian tentang implementasi safety riding for kids terhadap pengetahuan berlalu lintas pada siswa TK di Indramayu.

\section{Metode Penelitian}

Penelitian ini adalah penelitian eksperimen semu (quasi experiment) dengan pendekatan non randomized control group pre test post test design. ${ }^{6}$ Penelitian ini mengukur pengaruh dari implementasi keselamatan berkendara pada anak TK di Kelurahan Karanganyar Kabupaten Indramayu terhadap pengetahuan safety riding pada siswa TK. Metode yang diberikan yaitu berupa praktik cara penggunaan helm, mewarnai gambar safety riding dan menyanyikan lagu safety riding. ${ }^{7}$

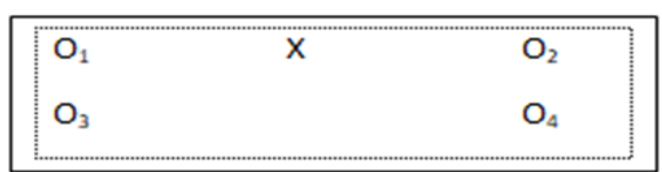

Gambar 5. Desain Penelitian non randomized control group pre test post test design

Penelitian ini dilakukan di sekolah TK Bustanul Athfal (sebagai kelompok perlakuan) dan TK Mutiara DWP Indramayu (sebagai kelompok kontrol). Sampel dalam penelitian ini yaitu siswa kelas TKB di 2 sekolah TK sebanyak 83 siswa. Terdiri dari 47 siswa sebagai kelompok kontrol dan 36 siswa sebagai kelompok yang diberi perlakuan. Pengambilan sampel didasarkan pada sekolah yang terletak di wilayah padat lalu lintas, banyak kendaraan mini bus (elf), angkot, ojek, dan sepeda motor berlalu lalang. Siswa yang diambil sebagai sampel merupakan siswa TKB yang diantar dan jemput ke sekolah menggunakan transportasi sepeda motor. 


\section{Hasil Penelitian}

\section{Analisis Univariat}

Tabel 1. Distribusi Frekuensi Pre Test Dan Post Test Pengetahuan Tentang Safety Riding

\begin{tabular}{|c|c|c|c|c|}
\hline \multirow[t]{2}{*}{ Pengetahuan } & \multicolumn{2}{|c|}{ Kelompok Perlakuan } & \multicolumn{2}{|c|}{ Kelompok Kontrol } \\
\hline & $\mathbf{F}$ & $\%$ & $\mathbf{F}$ & $\%$ \\
\hline \multicolumn{5}{|l|}{ Pre test } \\
\hline Baik & 28 & 77,8 & 34 & 72.3 \\
\hline Tidak Baik & 8 & 22,2 & 13 & 27.7 \\
\hline Jumlah & 36 & 100 & 36 & 100 \\
\hline \multicolumn{5}{|l|}{ Post test } \\
\hline Baik & 34 & 94,4 & 41 & 87,2 \\
\hline Tidak baik & 2 & 5,6 & 6 & 12,8 \\
\hline Jumlah & 46 & 100 & 47 & 100 \\
\hline
\end{tabular}

Berdasarkan Tabel 1 diperoleh hasil bahwa sebagian besar nilai pre test kelompok perlakuan kategori baik sebesar $77,8 \%$, kemudian setelah perlakuan diberikan (post

test) mengalami peningkatan menjadi baik 94,4\%. Pre test pada kelompok sebagian besar kategori baik sebesar $72,3 \%$ dan pada post test baik $87,2 \%$.

\section{Analisis Bivariat}

Tabel 2. Hasil Uji Wilcoxon, Perbedaan Nilai Pre test dan Post test Pengetahuan tentang Safety Riding pada Kelompok Perlakuan dan Kelompok Kontrol

\begin{tabular}{llllc}
\hline \multicolumn{2}{c}{ Pengetahuan Safety riding } & Mean & SD & p-value \\
\hline Kelompok & Pre test & 7,56 & 2,19 & 0.000 \\
Perlakuan & Post test & 9,47 & 2,48 & \\
\hline Kelompok & Pre test & 7.36 & 2.39 & 0,704 \\
Kontrol & Post test & 8.21 & 1.84 &
\end{tabular}

Berdasarkan Tabel 2 diperoleh hasil bahwa nilai rerata atau mean pada kelompok perlakuan sebelum diberikan implementasi safety riding adalah $7,56 \pm 2,19$ dan nilai mean post test adalah $9,47 \pm 2,48$ dengan $\mathrm{p}$ value 0,000 . Nilai rerata atau mean pada kelompok kontrol sebelum diberikan implementasi safety riding adalah 7,36 $\pm 2,39$

dan nilai mean post test adalah $8,21 \pm 1,84$ dengan $p$ value 0,704. Maka dapat disimpulkan bahwa pada kelompok perlakuan terdapat perbedaan pengetahuan tentang safety riding sebelum dan sesudah implementasi. Pada kelompok kontrol tidak terdapat perbedaan pengetahuan safety riding sebelum dan sesudah implementasi.

Tabel 3. Hasil uji Mann-Whitney, Pengaruh Pengetahuan tentang Safety Riding antara Kelompok Perlakuan dan Kelompok Kontrol

\begin{tabular}{lccc}
\hline \multicolumn{1}{c}{$\begin{array}{c}\text { Post test } \\
\text { pengetahuan }\end{array}$} & Mean & Mann-Whitney & P value \\
\hline $\begin{array}{l}\text { Kelompok } \\
\text { Perlakuan }\end{array}$ & 9,47 & 509.500 & 0,0001 \\
\hline $\begin{array}{l}\text { Kelompok } \\
\text { Kontrol }\end{array}$ & 8,21 & & \\
\hline
\end{tabular}


Berdasarkan Tabel 3 diperoleh hasil bahwa nilai mean post test kelompok pelakuan 9,47 dan nilai post test kelompok kontrol sebesar 8,21. Hasil uji Mann-Whitney

\section{Pembahasan}

Berdasarkan hasil penelitian menunjukkan pada kelompok perlakuan terdapat perbedaan pengetahuan tentang safety riding sebelum dan sesudah implementasi dengan $p$ value 0,000. Pada kelompok kontrol tidak terdapat perbedaan pengetahuan safety riding sebelum dan sesudah implementasi dengan $p$ value 0,704 terdapat pengaruh implementasi safety riding for kids terhadap pengetahuan tentang safety riding dengan $p$ value 0,001 .

Sebelum diberikan perlakuan, sebagian besar para siswa TK tidak menggunakan helm ketika berangkat maupun pulang kesekolah. Serta belum mengetahui tentang pentingnya penerapan safety riding. Setelah diberi perlakuan berupa praktik cara penggunaan helm, mewarnai gambar safety riding dan menyanyikan lagu safety riding, diperoleh hasil bahwa terdapat pengaruh implementasi safety riding for kids terhadap pengetahuan pada siswa TK. Hal ini terlihat dari helm yang dibagikan peneliti dipakai setiap hari, sudah mengetahui pentingnya safety riding dengan mewarnai gambar safety riding yang benar serta sangat antusias dan hapal lagu yang dinyanyikan tentang safety riding. Responden sudah mulai mengetahui pentingnya safety riding khususnya pemakaian helm ketika akan berangkat dan pulang ke sekolah. Hal ini menunjukkan ada pengaruh implementasi safety riding for kids terhadap pengetahuan responden. Hal ini sejalan dengan penelitian yang dilakukan oleh Wulandari yang mengatakan semakin luas pengetahuan seseorang maka semakin positif perilaku yang dilakukannya termasuk dalam perilaku safety riding. ${ }^{8}$

Menurut Nani, menjelaskan bahwa pengetahuan merupakan salah satu faktor yang diperoleh nilai $p$ value $0,0001<0,05$ yang berarti bahwa terdapat pengaruh implementasi safety riding terhadap pengetahuan tentang safety riding pada siswa TK.

mendasari seseorang dalam berperilaku. Pengetahuan bermanfaat bagi seseorang dalam memutuskan tindakan yang diambil benar atau salah sehingga seseorang yang memiliki pengetahuan yang luas maka akan lebih bijak dalam memutuskan suatu tindakan dan pengetahuan tersebut membuat perilaku yang seseorang lakukan bersifat langgeng atau berkelanjutan, termasuk dalam hal berkendara. $^{9}$

Pengetahuan memegang peranan penting dalam mencegah terjadinya insiden di jalan raya. Semakin seseorang memiliki pengetahuan yang benar dan memadai tentang moda jalan raya sebelum mereka mengemudikan kendaraan, memahami dan mematuhi aturan-aturan/kaidah-kadiah maupun rambu lalu lintas maka akan menurunkan potensi untuk mengalami kecelakaan. $^{10}$

Menurut Watson et al dengan memberi informasi berupa pentingnya keselamatan berkendara pada pengendara di Australia dapat meningkatkan pemahaman dan pengetahuan tentang tata cara berkendara yang aman dan selamat. ${ }^{11}$

Menurut Heily dengan memberikan kurikulum tentang keselamatan transportasi kepada anak pra-sekolah berupa pemberian pedoman tentang praktik menggunakan transportasi yang aman, pemberian gambar rambu lalu lintas, dan pengajaran yang diberikan oleh guru, membuat anak prasekolah di Washington mengetahui tentang menggunakan transportasi yang aman. ${ }^{12}$

Salah satu metode implementasi yang digunakan adalah dengan metode bernyanyi lagu safety riding. Hal ini juga sejalan dengan penelitian Saepudin, mengatakan bahwa anak yang sejak dini diperkenalkan dengan lagu- 
lagu akan lebih berkembang kecakapan emosi dan intelegensinya dibandingkan anak yang tidak pernah pernah mendengarkan lagu. Menurut Monty, dengan bernyanyi dan mendengarkan musik bermanfaat sebagai media latihan kecepatan menghafal khususnya bagi anak-anak, seperti menghafal lirik lagu, jingle-jingle iklan di TV. Dengan kata lain lagu dapat dijadikan alat untuk mempertajam kecerdasan serta memperkaya daya nalar dan mengunggah emosi anak. ${ }^{14}$

\section{Kesimpulan}

Penelitian mengenai implementasi keselamatan berkendara pada anak (safety riding for kids) terhadap pengetahuan keselamatan berlalu lintas pada siswa TK di Kabupaten Indramayu, didapat kesimpulan :

1. Pada kelompok perlakuan terdapat perbedaan pengetahuan tentang safety riding sebelum dan sesudah implementasi dengan $p$ value 0,000

2. Pada kelompok kontrol tidak terdapat perbedaan pengetahuan safety riding sebelum dan sesudah implementasi dengan $p$ value 0,704

3. Terdapat pengaruh implementasi safety riding for kids terhadap pengetahuan tentang safety riding dengan $p$ value 0,001 .

\section{Saran}

Mengacu pada hasil penelitian, pembahasan serta kesimpulan maka dapat di kemukakan beberapa saran sebagai berikut:

1. Diperlukan adanya kesadaran dari orang tua siswa tentang pentingnya safety riding untuk anak, khususnya terkait pemakaian helm.

2. Pihak sekolah sebaiknya melakukan pengawasan tentang pentingnya safety riding khususnya pemakaian helm pada siswa baik pada saat diantar maupun pulang sekolah .

3. Pihak sekolah sebaiknya membuat peraturan atau kebijakan tentang kewajiban menggunakan helm pada siswa, sehingga siswa ketika pergi dan pulang sekolah selalu memakai helm.

\section{Daftar Pustaka}

1. WHO. 2015. Global Status Report on Road Safety, WHO Library.

2. Badan Pusat Statistik Provinsi Jawa Barat. 2016. Jumlah Kecelakaan Lalu Lintas Menurut Polres dan Kendaraan yang Terlibat di Provinsi Jawa Barat. Bandung.

3. Polres Indramayu. 2019. Data Kecelakaan Lalu Lintas. Indramayu.

4. Goniewicz, K, Goniewich, M., Pawlowski, W., Fiedor, P. 2017. Children Road Traffic Injuries in Poland, Journal of Pol J Public Health 2017;127(1): 44-48.

5. Liu, X., Yang, J., Chen X., Li, L. 2015. Knowledge, Attitudes and Behaviors on Child Passenger Safety among Expectant Mothers and Parents of Newborns: A Qualitative and Quantitative Approach. Journal of Pone, January 6. 2016.

6. Notoatmodjo, S. 2003. Pengantar Ilmu Pendidikan Kesehatan dan Ilmu Perilaku Kesehatan. Yogyakarta: Andi offset.

7. Wulansari, R dan Triyono. 2017. Safety for Kids Indonesia. Jakarta: Bisnis 2030.

8. Wulandari, S., Jayanti, S., Widjasena, B. 2017. Faktor-faktor yang Berhubungan dengan Perilaku Berkendara Aman (Safety Riding) pada Kurir Pos Sepeda Motor di PT. Pos Indonesia Cabang Erlangga Semarang. Jurnal Kesehatan Masyarakat Vol. 5. No. 5. Universitas Diponegoro, Semarang.

9. Nani, S. 2010. Perilaku Pengendara Sepeda Motor pada Remaja terhadap Risiko Kecelakaan Lalu Lintas. http://adln.lib.unair.ac.id/

10. Pamungkas, N,S. 2014. Mengenal Perilaku Pengendara Kendaraan dalam Upaya Mencegah Terjadinya Kecelakaan di Jalan Raya. Teknis. Vol.9, No.1. hal. 13-18.

11. Watson, B., Tunnicliff, D., White, K., 
Schonfeld, C., Wishart, D., 2007. Psychological and Social Factors Influencing Motorcycle Rider Intentions and Behaviour. Document Retrieval Information. Quensland University of Technology, Australia.

12. Heily, T. 2003. Transportation Safety Education Curriculum for Preschool Children. Enterprise for Progress in the Community (EPIC). Washington. USA

13. Saepudin, A., 2010. Media Musik Latar dan Dampaknya dalam Meningkatkan Emosi Positif Siswa pada Pembelajaran Pendidikan Agama Islam di SMA Negeri ! Ciledug Cirebon. Tesis. UIN Walisongo.
Semarang.

14. Monty. 2003. Mendidik Kecerdasan. Jakarta: Pustaka Populer Obor. 